\title{
PENINGKATAN KINERJA USAHA KOPI MELALUI PELATIHAN KEUANGAN SEDERHANA, PEMASARAN DAN PENINGKATAN KOMPETENSI SUMBER DAYA MANUSIA PADA PENGUSAHA KEDAI KOPI DI UJUNGBERUNG
}

\author{
Dwi Puryati \\ dwi.puryati@ekuitas.ac.id \\ Susinah Kuntadi \\ susikuntadi@gmail.com \\ Teguh Iman Basuki \\ teguhib@ekuitas.ac.id
}

SEKOLAH TINGGI ILMU EKONOMI (STIE) EKUITAS

\begin{abstract}
ABSTRAK
Pesatnya pertumbuhan peminum kopi di Indonesia yaitu $8 \%$ yang melebihi pertumbuhan peminum kopi dunia (6\%) berimbas pada peningkatan jumlah industri kopi. Selain itu perkembangan industri juga dipengaruhi oleh industri kopi dunia. Peningkatan yang signifikan terjadi pada industri hilir sebagaimana terlihat pada maraknya kafe-kafe dan kedai kopi di berbagai daerah. Di daerah Ujungberung Bandung bermunculan kedai-kedai kopi baik yang kecil maupun yang besar. Namun demikian, kedai-kedai kopi kecil di daerah Ujungberung masih belum mampu menghadapi persaingan dengan kedai-kedai kopi yang sudah dikelola dengan baik. Oleh karena itu, perlu adanya pembinaan dalam manajemen usaha. Tujuan pengabdian ini adalah memberikan pemahaman pengelolaan keuangan, pemasaran secara online dan peningkatan kompetensi barista maupun manajemen sumber daya manusia. Setelah mengikuti pelatihan, terjadi pemingkatan pemahaman pelaku usaha kedai kopi di wilayah Ujungberung yang berhubungan dengan pengelolaan keuangan, pencatatan sederhana, pengemasan dan pemasaran online. Selain itu pemahaman dan keterampilan mereka dalam membuat dan menyajikan produk terutama specialty coffee juga mengalami peningkatan. Dengan pengabdian ini diharapkan kedai-kedai kopi kecil di di wilayah Ujungberung dapat meningkatkan kinerja sumber daya manusia dan pemasaran, sehingga omzet dan kinerja keuangan pun meningkat.
\end{abstract}

Kata kunci: Keuangan, Pemasaran, Specialty Coffee, Sumber Daya Manusia.

\section{PENDAHULUAN}

Indonesia merupakan produsen kopi urutan keempat dunia, setelah Brasil, Vietnam dan Kolombia (ICO, 2017). Sementara itu, sebagai produk perkebunan Indonesia, kopi berada di urutan keenam setelah kelapa sawit, karet, gula, teh, dan kakao. Industri kopi di Indonesia sekarang ini sudah mulai berkembang dengan pesat, para petani kopi sekarang tidak lagi asalasalan dalam mengelola atau dalam penanaman kopi sampai pada panen. Peningkatan kualitas kopi nusantara dipengaruhi oleh semakin banyaknya peminum kopi yang sudah mulai 
memerhatikan kualitas dari kopi yang mereka minum. Semakin maraknya kaum milenial yang mulai menggemari kopi khususnya specialty coffee atau kopi arabika yang disajikan tanpa gula, memicu para petani untuk menghasilkan kopi yang berkualitas.

\section{Data dari International Coffee} Organization (ICO), menunjukkan pertumbuhan peminum kopi di Indonesia berkembang pesat, lebih daripada pertumbuhan dunia, yaitu $8 \%$ untuk pertumbuhan peminum kopi Indonesia sedangkan pertumbuhan peminum kopi dunia hanya mencapai 6\%. Perkembangan industri kopi dunia juga berimbas pada industri kopi Indonesia. Industri kopi Indonesia mengalami peningkatan pada industri hilir sebagaimana terlihat pada maraknya kafe-kafe dan kedai kopi dewasa ini termasuk khususnya di daerah Ujungberung Bandung bermunculan kedaikedai kopi baik yang kecil maupun yang besar. Kedai kopi dewasa ini telah mengubah cara masyarakat dalam meminum kopi tidak hanya untuk mengusir kantuk saja tapi sudah menjadi gaya hidup bagi orang tua maupun anak muda. Kopi yang enak tersaji berkat dari keterampilan seorang barista di kedai kopi.

Dari survey pendahuluan diperoleh informasi bahwa kondisi usaha kedai-kedai kopi di sekitar daerah Ujungberung dalam beberapa tahun ini tidak mengalami perkembangan yang signifikan, bahkan beberapa unit usaha mengalami penurunan omzet penjualan dan penurunan keuntungan. Kedai-kedai kopi kecil di sekitar Ujungberung mengalami permasalahan, yaitu (1) penurunan kinerja keuangan (omzet dan keuntungan) (2) belum melakukan tertib administrasi (2) Permasalahan dalam memasarkan kedai kopi karena saat ini persaingan sudah mulai ketat (3) Permasalahan dalam pembuatan kopi yang berkualitas sesuai dengan keinginan konsumen karena untuk saat ini permintaan minuman kopi itu sudah sangat beragam terutama specialty coffee.
Dengan kondisi inilah kami tim dosen STIE Ekuitas dengan bekerja sama dengan Dewaji Coffee bermaksud melakukan pengabdian dengan tujuanuntuk membantu meningkatkan kinerja dan omzet kedaikedai kopi kecil di sekitar Ujungberung. Kegiatan pengabdian ini direncanakan dengan memberikan materi terkait permasalahan usaha kecil sesuai dengan keahlian masing-masing yang meliputi pelatihan manajemen keuangan, pencatatan sederhana, pemasaran produk, dan kompetensi barista.

Untuk melakukan pelatihan manajemen usaha, materi yang akan diberikan meliputi:

a. Keuangan akan diberikan penjelasan bagaimana memulai usaha, mengatur modal usaha, biaya investasi, biaya operasional.

b. Akuntansi, akan diberikan pelatihan mengenai pembukuan sederhana.

c. Pemasaran, akan diberikan materi pengemasan dan desain produk.

d. Kompetensi Barista, akan diberikan materi bagaimana membuat dan menyajikan kopi yang enak sesuai dengan standar atau sesuai dengan kemajuan kopi generasi ketiga.

Sehingga manfaat yang akan didapat dari pengusaha kedai kopi dantaranya:

a. Pelatihan keuangan sederhana agar para pengusaha kopi mengert dan paham mengatur permodalan, biaya operasional dan biaya investasi sehingga dapat memulai usaha dengan baik serta dapat mengembangkan usaha.

b. Pelatihan memasarkan produk dengan menggunakan media dalam jaringan sehingga pasaran mereka menjadi tidak dibatasi oleh lokasi sehingga omzet mereka daharapkan dapat lebih meningkat.

Peningkatan kemampuan sumber daya barista sebgai modal utama bagi usaha kedai kopi melalui pelatihan barista yang dantaranya pengetahuan tentang pemilihan kopi berkualitas, penggunaan dan pemilihan alat pengolahan dan penyajan 
kopi yang dsesuakan dengan situasi saat ini.

\section{METODOLOGI PELAKSANAAN}

Metode pelaksanaan dalam pengabdian ini adalah sebagai berikut:

Tabel 2.1

Metode Pelaksanaan Pengabdian

\begin{tabular}{|c|c|c|}
\hline $\begin{array}{c}\text { TAHAP } \\
\text { AN }\end{array}$ & METODE & HASIL \\
\hline $\begin{array}{l}\text { Tahap } \\
\text { awal }\end{array}$ & $\begin{array}{l}\text { - } \text { Berdiskusi } \\
\text { dengan } \\
\text { pelaku } \\
\text { usaha } \\
\text { kedai kopi } \\
\text { kecil di } \\
\text { Ujungberu } \\
\text { ng } \\
\text { - Menyebark } \\
\text { an } \\
\text { kuesioner } \\
\text { tentang } \\
\text { masalah } \\
\text { yang } \\
\text { dihadapi } \\
\text { dan } \\
\text { pemahama } \\
\text { n } \\
\text { manajeme } \\
\text { n usaha } \\
\text { - Mempersia } \\
\text { pkan } \\
\text { bahan- } \\
\text { bahan } \\
\text { pelatihan } \\
\text { dan } \\
\text { pendekatan } \\
\text { terhadap } \\
\text { pelaku } \\
\text { usaha } \\
\text { kedai kopi } \\
\text { kecil di } \\
\text { Ujungberu } \\
\text { ng } \\
\text { Bandung } \\
\text { Koordinasi } \\
\text { dengan } \\
\text { pihak } \\
\text { manajeme } \\
\text { n Dewaji }\end{array}$ & 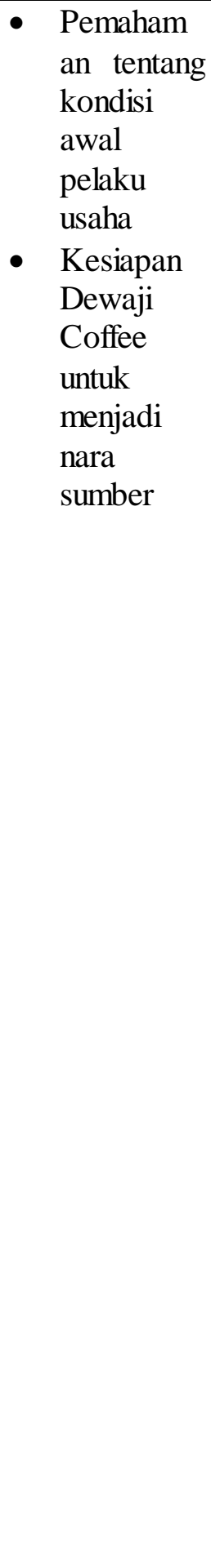 \\
\hline
\end{tabular}

\begin{tabular}{|c|c|c|}
\hline & $\begin{array}{l}\text { Coffee } \\
\text { tentang } \\
\text { waktu dan } \\
\text { materi } \\
\text { pelatihan }\end{array}$ & \\
\hline $\begin{array}{l}\text { Tahap } \\
\text { pelaksan } \\
\text { aan }\end{array}$ & $\begin{array}{ll}\text { - } & \text { Pelatihan } \\
\text { Manajeme } \\
\mathrm{n}\end{array}$ & $\begin{array}{l}\text { - Modul } \\
\text { pelatihan } \\
\text { manajeme } \\
\mathrm{n} \\
\text { keuangan, } \\
\text { pembukua } \\
\mathrm{n} \\
\text { sederhana, } \\
\text { pemasaran } \\
\text { usaha bagi } \\
\text { kecil } \\
\text { Telah } \\
\text { diimpleme } \\
\text { ntasikan } \\
\text { pembukua } \\
\mathrm{n} \\
\text { sederhana, } \\
\text { pemasaran } \\
\text { online, } \\
\text { manajeme } \\
\text { n kas, } \\
\text { Telah } \\
\text { dïmpleme } \\
\text { ntasikan } \\
\text { pembuata } \\
\mathrm{n} \\
\text { penyajian } \\
\text { kopi } \\
\text { berkualita } \\
\text { s }\end{array}$ \\
\hline $\begin{array}{l}\text { Tahap } \\
\text { akhir }\end{array}$ & $\begin{array}{l}\text { Monitoring } \\
\text { dan Evaluasi }\end{array}$ & $\begin{array}{l}\text { Pendampingan } \\
\text { sampai terjadi } \\
\text { peningkatan } \\
\text { kinerja } \\
\text { keuangan dan } \\
\text { Peningkatan } \\
\text { keterampilan } \\
\text { barista. }\end{array}$ \\
\hline
\end{tabular}




\section{HASIL DAN LUARAN}

Hasil pelaksanaan kegiatan berdasarka metode pelaksanaan pengabdian adalah sebagai berikut :

Tahap Awal

Hasil pelaksanaan kegiatan yang pertama adalah berdiskusi dengan pelaku usaha kedai kopi kecil di Ujungberung dan memberikan kuesioner tentang masalah yang dihadapi dan pemahaman manajemen usaha. Hasil dari kuesioner tersebut menunjukkan dari 10 kedai kopi kecil di Ujungberung hanya sekitar 20\% yang mengerti dan sudah menerapkan manajemen usaha, sisanya masih belum menerapkan manajemen usaha secara baik. Mereka memulai usaha tanpa ada perencanaan awal, menetapkan harga jual kopi berdasarkan perkiraan dan tidak dihitung secara benar, tidak pernah melakukan pencatatan hasil usaha dan tidak pernah menghitung laba atau rugi secara berkala. Dalam membuat kopi pun mereka melakukan secara otodidak tanpa ada komposisi standar untuk membuat kopi. Akibatnya kopi yang dihasilkan rasanya beragam dari waktu ke waktu, sehingga kepuasan konsumen akan kualitas kopi menurun.

Selanjutnya Tim pengabdian masyarakat koordinasi dengan pihak manajemen Dewaji Coffee untuk menjadi narasumber dalam pelatihan barista, dan mempersiapkan bahan-bahan materi pelatihan. Dari pihak STIE Ekuitas kita memberikan pelatihan tentang keuangan, pengemasan desain produk, dan manual brew untuk barista. Pihak Dewaji Coffee menyiapkan materi kelas tentang basic barista yang meliputi sejarah dan teori kopi paska panen, barista hospitality dan basic espresso dan latte art.

Pelaksanaan

Hasil pelaksanaan kegiatan pengabdian pada masyarakat diuraikan sebagai berikut

1. Kegiatan pengabdian "Peningkatan Kinerja Usaha Kopi melalui Pelatihan Keuangan Sederhana, Pemasaran dan
Peningkatan Kompetensi Sumber Daya Manusia Pada Pengusaha Kedai Kopi di Ujungberung" dilaksanakan pada hari Rabu tanggal 26 Juni 2019 di Café Dewaji Coffee Jl. Rumah Sakit No. 10a Ujungberung Bandung mulai jam 8.30 sampai dengan jam 17.30.

2. Kegiatan pengabdian dihadiri oleh 4 orang peserta yang merupakan perwakilan dari kedai kopi anggota komunitas Keluarga Besar Pedangan Kopi (KBPK) dengan omzet masih di bawah tiga ratus ribu rupiah. Peserta hanya 4 orang dikarenakan pelatihan untuk peningkatan kompetensi basic barista memerlukan biaya yang tidak murah dan akan efektif jika peserta sedikit karena pelatihan ini dilengkapi dengan praktik. Materi pelatihan disampaikan oleh tim pengabdian masyarakat STIE Ekuitas dan bekerjasama dengan manajemen Dewaji Coffee.

3. Pelatihan basic barista merupakan pelatihan dalam bentuk praktek bagaimana membuat kopi manual brew dan milk base terutama bagaimana membuat espresso dan latte art, bagaimana membedakan antara cappucino dan latte yang selama ini sering salah kaprah. Sedangkan untuk manual brew nya mereka belajar bagaimana membuat kopi hitam yang enak tanpa gula dengan mempergunakan alat-alat seperti V60, Flatbottom, desember, konno dan lain-lain.

4. Kemampuan peserta dalam pelatihan basic barista ini dapat dikatakan baik terutama dalam manual brew sedangkan untuk milk base nya masih agak kurang dikarenakan mereka sebelumnya belum pernah menggunakan mesin untuk membuat espresso. Para peserta sangat senang mendapatkan informasi dan pengetahuan baru bagaimana meningkatkan penjualan dengan memperhatikan manajemen usaha dan peningkatan kemampuan dari baristanya sehingga sekarang bisa menyajikan kopi sesuai dengan keinginan pelanggan dan 
dapat mengikuti trend ngopi generasi ketiga.

Evaluasi

- Peningkaan kinerja kedai kopi kecil melalui pelatihan basic barista dapat meningkatkan pemahaman tentang :

1. Pemahaman sejarah kopi.

2. Pemahaman perbedaan pengolahan kopi pasca panen.

3. Perbedaan kopi robusta dan arabika.

4. Peningkatan kemampuan menyeduh kopi manual brew

5. Peningkatan kemampuan dalam membuat kopi milk base terutama cappuccino dan latte

6. Pelayanan terhadap konsumen.

- Peningkaan kinerja kedai kopi kecil melalui pelatihan manajemen keuangan dan pembukuan sederhana dapat meningkatkan pemahaman tentang:

1. Penyusunan studi kelayakan usaha.

2. Pengelolaan keuangan usaha.

3. Pembukuan sederhana.

4. Penyusunan laporan keuangan.

- Peningkaan kinerja kedai kopi kecil melalui pelatihan pengemasan produk sehingga peserta dapat meningkatkan pemahaman tentang:

1. Pengemasan dengan cup coffee untuk pemesanan yang dibawa pulang.

2. Desain kemasan cup coffee sehingga lebih menarik.

Faktor Pendukung dan Penghambat Kegiatan

Faktor pendukung dan penghambat dalam pelaksanaan pengabdian sebagai berikut:

1. Faktor Pendukung

a. Kedai kopi kecil mitra KBPS membantu kelancaran dan sangat tertarik untuk mengikuti pelatihan baik yang disampaikan oleh tim pengabdian masyarakat maupun yang disampaikan oleh Manajemen Dewaji Coffee.

b. Manajemen Dewaji Coffee sangat membantu kelancaran dan kesuksesan pelaksanaan kegiatan pelatihan meskipun dengan dana yang terbatas.

2. Faktor Penghambat

a. Keterbatasan waktu pelaksanaan pelatihan.

b. Biaya pelatihan barista yang relatif mahal.

c. Banyaknya kedai kopi kecil yang masih mau mengikuti pelatihan basic barista.

d. Monitoring dan evaluasi tentang peningkatan kinerja usaha kopi membutuhkan waktu yang cukup lama.

Target dalam pelaksanaan pelatihan peningkatan kinerja ini adalah pelaku usaha kedai kopi kecil di lingkungan Ujungberung Bandung. Target peserta adalah 30 pelaku usaha.

Luaran yang dihasilkan :

1. Pemahaman dan implementasi manajemen usaha, terutama dari sisi pengelolaan keuangan, administrasi pembukuan, dan strategi pemasaran

2. Pemahaman dan praktik membuat dan menyajikan minuman kopi yang berkualitas

3. Peningkatan kinerja keuangan

4. Publikasi hasil pengabdian

Untuk lebih jelasnya berikut disajikan rencana target capaian luaran yang diharapkan di akhir pengabdian ini.

Tabel 3.1

Tabel Rencana Target Capaian Luaran

\begin{tabular}{|c|lll|}
\hline No & \multicolumn{3}{|c|}{ Jenis Luaran } \\
\hline 1 & Publikasi ilmiah di jurnal nasional \\
\hline 2 & Peningkatan omzet pada mitra \\
\hline 3 & $\begin{array}{l}\text { Peningkatan kuantitas dan kualitas } \\
\text { produk }\end{array}$ \\
\hline 4 & $\begin{array}{l}\text { Peningkatan pemahaman dan } \\
\text { keterampilan }\end{array}$ \\
\hline
\end{tabular}




\section{KESIMPULAN}

Pengabdian

masyarakat

yang

dilaksanakan oleh dosen dosen ekutas bag pelaku usaha keda kop dapat terlaksana dengan baik berkat kerjasama dengan dewaji coffe sebagai pakar dalam kegiatan pengabdian pada masyarakat kali ini, kemampuan peserta dalam pelatihan dasar barista ini dapat dikatakan baik terutama dalam manual brew sedangkan untuk milk base nya masih agak kurang dikarenakan mereka sebelumnya belum pernah menggunakan mesin untuk membuat espresso. Para peserta sangat senang mendapatkan informasi dan pengetahuan baru bagaimana meningkatkan penjualan dengan memperhatikan manajemen usaha dan peningkatan kemampuan dari baristanya sehingga sekarang bisa menyajikan kopi sesuai dengan keinginan pelanggan dan dapat mengikuti trend ngopi generasi ketiga. Dalam kegatan inijuga terdapat bebrapa kendala diantaranya keterbatasan waktu pelaksanaan pelatihan biaya pakar dibidang barista yang relatif mahal, banyaknya kedai kopi kecil yang masih mau mengikuti pelatihan dasar barista.

\section{DAFTAR PUSTAKA}

Abubakar, A dan Wibowo. (2014). Akuntansi Untuk bisnis Usaha Kecil dan Menengah. Jakarta: Grasindo.

Aries, H. P. (2013). Sukses Mengelola Keuangan Usaha Mikro, Kecil, Menengah. Jakarta: Elex Media Computindo.

Hoffman, J. (2018). The World Atlas of Coffee "From Beans to Brewing Coffees Explored, Explained and Enjoyed". Mitchell Beazly.

Lila, B. (2018). Strategi Peningkatan Daya Saing Usaha Kecil dan Menengah. Medan: Lembaga penelitian dan Penulisan Ilmiah Aqli.

Kementerian Perindustrian RI. (2017).

Peluang Usaha IKM Kopi. Jakarta
Menteri Tenaga Kerja dan Transmigrasi RI. (2013). SKKNI BARISTA. Jakarta. 